【関東支部研究会記録】

[1998 年 11 月 21 日：東京大学農学部]

統一テーマ

「フードシステムからみた食料・農業の基本問 題」

\section{調査会食料部会の議論と今後の食料・食品政 策}

\section{女子栄羪大学 吉田 企世子}

本部会において討議された内容の概要は(1) 世界の食料需給について、(2)我が国の食料安 全保障のあり方、(3)我が国が食料・農業分野 において国際的に果たすべき役割、(4)食品産 業政策のあり方、(5)消費者関連施策のあり方 などに関する内容である。これらの中で、と くに議論が紛紏したのは食料自給率をどう位 置付けるか、自給率目標を数字で具体的に示 すか否かであり、その点で統一見解が得られ なかったことは、中間答申に示された通りで ある。最終的には、国内農業生産を食料供給 の基本に位置付け、可能な限りその維持 ·拡 大を図っていくこと。そして食料自給率は、 農業者、食品産業、消費者、および行政など 全般に関わる幅広い問題であることなどのた めに、具体的目標は示されなかった。しか し、せめて我が国の農耕地を現在の面積以下 には縮小しないことを明確に示し、その取り 組みについての示唆があっても良かったので はないかと思っている。そのために生産者が 意欲的に農業に取り組める条件は何である か、消費者がその生産物を賢く食生活に取り 入れるための啓発をどう行うか、食品産業が 国内農産物を活用するための方策は。それぞ れの立場にある者が同じ方向でこれらの問題 に関わることが必要であろう。

日頃、野菜の成分を分析している中で感じ ることは、価格では輸入品の方が活用しやす いが、味や栄養価などは一般論として国産品 に及ばないのである。農産物の評価は内部品
質によってなすべきであることを消費者は認 識することである。そして食べ物は心と身体 を健全に保つ基本であることを自覚し、何を どのように食べるべきかを考え、実践するこ と。生産者はそれに対応できる農産物生産に 向けての取り組みが必要であり、消費者が求 める農産物が提供されなければならないであ ろう。それには行政の援助も必要である。

\section{農業部会の論議と今後の食料・農業政策 東京大学大学院 生源寺 真一}

株式会社問題、価格政策の改革、環境保全 型農業の 3 つのテーマに絞って、農業部会で の集約の要点を紹介するとともに、フードシ ステム研究との関わりを念頭において、以下 の論点を提示した。

第 1 の株式会社問題については、一面では 農業生産の主体の行動に着目した事後規制の ありかたの問題として捉えなおすことが可能 であり、したがって、日本農業における良好 な耕作の原則のありかたが問われることにな る。また、株式会社問題の背景には、技術革 新や情報化の進展による農業と川下産業のシ ームレス化の急速な進行がある。フードシス テムという枠組みのもとであらためて農業の 担い手問題を考える必要がある。

第 2 の価格政策への市場原理の活用に関し ては、こうした政策路線が製品の差別化空間 を拡大する作用を持つことに注目すべきであ る。また、取引形態の自由な選択も広い意味 での市場原理の活用に含まれる。だとすれ ば、取引の態様によって「価格」の持つ意味 も一様ではないはずである。このことは、な んらかのかたちで「市場価格」を用いる農業 政策の持つ本質的な困難を示唆している。

第 3 の環境保全型農業については、フード システム全体としてみたときの環境への負荷 という視点も欠かせない。食料のロスの軽減 
という問題をとっても、負荷の他へのたんな る転嫁であってはならないはずである。ま た、外部不経済を内部化するという点では、 農業生産の健全性を製品差別化の戦略ファク ターとする観点から、ラベリングによるサポ 一トの有効性が興味深い問題として存在す る。

\section{フードシステムからみた食料・農業の基本問} 題

日本大学 高橋 正郎

農地改革、現行農業基本法制定に次ぐ戦後 第 3 の農政大改革といわれる今回の「食料 . 農業・農村基本法」の制定にかかわる 3 年越 しの「基本問題調查会」や昨年末の「農政改 革大綱」などの答申や制定の内容について、 フードシステム論の立場から検討するとやや 不満に感ずるところがある。

その第 1 は、前 2 回の農政改革では経済理 論をバックにした厳密な基本問題への遡及が あったのに対して、今回の論議はやや対象療 法的な政策論争に終始し、困難な局面に対す る新しいパラダイムの提示がないこと。

第 2 に、前回の基本法制定時と決定的に違 うことは、これ以上の財政負担が求められな い環境の下での農政改革であるため、関係者 の利害対立を超える高い次元での理論に裏付 けられた理念が不可欠であるにも関わらず、 それが浮き彫りにされていないこと。

第 3 に、今日的な食料・農業問題の根底に 「食」と「農」との乘離という事実があり、そ れから多くの問題が派生してきているにも関 わらず、それへの配慮がない。すなわち消費 者の食ニーズと日本農業の間の内在するミス マッチ是正への対応がその核にないこと。

「土地問題」や「担い手問題」は論議されて いても「何を作るか」の論議がない。それを 解くにも、消費者や食料消費の 8 割を占める
食品産業のユーザーとの関係を明確にしなけ ればならないが、しかし、今回の論議や答申 は、食品産業と農業との連携を基本軸とする 発想はないことなどについてである。

要するに今日の食料・農業にかかわる基本 問題は、フードシステムの観点からこれを体 系的に整理し、農業と食品産業と食料消費を つなぐ論理の上に構築されるべきものと考え られるのである。

新たな食品流通政策の展開について 農林水産省食品流通局 西藤 久三

1. 食品産業は、農業と並んで食料供給シス テムを担う地位にあり、国民経済の一割産 業として雇用の場と所得機会を提供してい る。しかしながら、最近の食品産業をめぐ る情勢をみると、食料消費全体が低調な動 きにある中で、食生活の変化、国際化の進 展など大きな構造変化に直面している。

2.このため、(1)消費者視点の重視、(2)食品 の安全性の確保、(3)食品産業と農業との連 携の強化及び食品産業の経営基盤の強化、

(4)流通コストの低減と流通効率の向上、(5) 国際化の進展への対応等の視点から新たな 食品産業政策を展開する。

3. 具体的には、当面以下の制度改正、施策 の展開を図る。

(1)食品の表示・規格制度の見直し、強化 消費者の選択に資する等のため、すべて の生鮮食料品に原産地表示をお願いする等 表示制度の充実と規格制度の合理化を図る ( J A S 法改正案を今国会に提出した)。 (2)食品の安全性確保と食生活の見直し 生産から消費に至る各段階に打ける食品 の安全性確保対策の充実を図る。また、わ が国の食の現状課題について情報の提供を 行うとともに食料消費の改善及び農業資源 の有効利用に資するため、健全な食生活に 
関する指針の策定を行う。

(3)食品産業と国内農業との連携強化及び食 品産業の経営基盤の強化

食品産業と農業の双方の活性化に資する 望ましい食品産業と農業の連携のあり方、 その推進手法等について法制度化を含め早 急に検討を行う。また、食品産業の技術力 や経営基盤の強化を図るための支援を行う とともに総合的な環境対策を講ずる。

(4)食品流通のコスト低減と食品流通業の活 性化

卸売市場の新たな展開と活性化を図るた め卸売市場法を改正するほか食品流通業の 活性化を図るため支援を強化する。
【関東支部研究会記録】

[1999 年 3 月 13 日 : 東京大学農学部]

統一テーマ

「食品ロスとフードシステムの取り組み」

食料の廃棄を考えよう。どうする自給率・生 ゴミ・地球環境一食品のロス・推計の意義と 取り組み一

農林水産省統計情報部 山本 害孝

食料自給率が $42 \%$ に過ぎない日本では、 8 億人の飢餓人口を抱える世界各国から大量の 食料を輸入しているにもかかわらず、消費者 の鮮度志向等豊かな食生活の追求を背景に、 食品の加工・流通から消費に至る各段階にお いてさまざまな形態で大量の食品ロス（可食 食料の廃棄）が生じている。わが国において は、食品ロスの数量把握は未だ十分に行われ ておらず、また、食品ロスへの取組は、生ゴ ミの視点が先行している。

この問題には、次の 6 つの視点が挙げられ る。すなわち、(1)わが国の食料自給率の低 下、(2)生ゴミに起因するさまざまな不効用、 (3)余分な食料の生産によって生じる地球環境 への負荷、(4)公衆衛生の確保、(5)機会ロスと 商品廃棄との間のミクロマクロジレンマ、最 後に6飢餓問題である。

海外に目を向けると、米国では、年間の食 料廃棄が食料供給量の $27 \%$ に相当する 4,360 万トンに達しているという食品ロス統計を公 表し、1997年の全米サミットを契機として、 官民連係して、食品ロスを回収し、飢餓撲滅 に生かす国民的運動を成功裡に推進してい る。

フード・システムに関係する方々の食品口 スに対する認識が深まることを期待し、この ような食品口ス問題をめぐる状況の一端を紹 介した。 
食べずに捨てた家庭の食品

セゾン総合研究所 木下 ヒデミ

家庭食の外部化が進み調理くずが減少して いる反面、食べ残しは増加しているといわれ ている。生ごみの問題やわが国の食料自給率 の低下などの点から、家庭における食品の無 駄使いを減らすことが望まれる。

1995年 6 月、首都圈の 100 家庭を対象に、 1 週間実際に食べずに捨てた食品（大根の 皮、無の葉など（エコ部分について）につい て調查した。

調査初日に、それまで家庭内に保存されて いた食品のうち、今後食べないとして廃棄し たのは平均 $2113 \mathrm{~g}$ （エコ部分 $66 \mathrm{~g}$ )。その内訳 は、乾曙、豆腐、水産加工品などの市販加工 食品 $58 \%$ 、野菜、魚介、肉類などの調理素材 $34 \%$ 、煮物、白飯などの自家製食品 $8 \%$ であ った。

日常的な廃棄であるその後の 6 日間は、1 日平均 $186 \mathrm{~g}$ (エコ部分53g)。その内訳は、調 理素材 $62 \%$ 、自家製食品 $20 \%$ 、市販加工食品 18\%であった。

1 週間の廃棄総量は $3228 \mathrm{~g}$ で、理由は「古


で「腐っていた $(11 \%)$ 」。その多くは冷蔵庫 （48\%）や冷凍庫（14\%）に置かれていたもの である。廃棄量は主婦の年代が高いほど、子 供の年齢が高いほど多い傾向であった。また 廃棄された約 3 割はもらい物で、その内の 3 割は全く手付かずのままであった。調査期間 中に食べ物を有効に使い切るためにエコクッ キングやリフォームクッキングをした人は、 100 人中 75 人であった。

1 週間の廃棄食品を購入価格に換算すると 1 家庭約 2,700 円になると同時に、生ごみと して当然その処理費もかかることから、これ らの食べずに捨てる食品を極力少なくする工 夫が求められている。
外食産業におけるリサイクルの取り組み

日本フードサービス協会 中井尚

1997 年の外食産業の市場規模は 29 兆 6,778 億円で、対前年比 $2.5 \%$ 増となっている（中食 などが含まれる広義の市場規模は 33 兆 2,270 億円)。1975年に比べ、22年間で約3.4倍の規 模に成長したことになる。このうち、レスト ランなどの一般飲食店が主体の営業給食部門 が 14 兆 9,029 円、ビヤホール・バーなどのア ルコールを主体とした部門は 5 兆 4,354 億円 などとなっている。

また、外食産業はいわゆる労働集約型産業 であり、その店舗数は全国で 83 万 6,400 店、 従業者数は約 411 万 5,000 人にのぼり、大き な雇用力をもっている。

外食産業全体でどの程度の食品ロス（調理 過程で生じるいわゆる調理くず、及び食べ残 し）があるのかについては、残念ながら正確 な統計データがない。ここでは、以下の $3 つ$ の生ごみに関する実態調査データを紹介して 参考に供したい。

一つ目は、当協会が1995年に仙台市内の 16 （和食 $8 、$ 洋食 8) の会員店舗を対象に実施し たものである。それによると 1 店舗当たりの 廃棄物量の平均は $35.1 \mathrm{~kg} /$ 日でそのうち生ご みは $23.3 \mathrm{~kg} /$ 日となっいる。

二つ目は、東京都内で業態別に調査したも のである。それによるとファーストフードで は生ごみが同じく $21 \mathrm{~kg} /$ 日、その他のごみが $19 \mathrm{~kg} /$ 日で合計 $40 \mathrm{~kg} /$ 日であり、ファミリ ーレストランの場合は、生ごみが $40 \mathrm{~kg} /$ 日、 その他のごみが $52 \mathrm{~kg} /$ 日で合計 $92 \mathrm{~kg} /$ 日で あり、全体の平均では生ごみが $30 \mathrm{~kg} /$ 日、そ の他のごみが $36 \mathrm{~kg} /$ 日で合計 $66 \mathrm{~kg} /$ 日とい う数值となっている。

三つ目は、1997年に東京都清掃局が行った 事例調査（「事業系生ごみに係る使用量・廃棄 量及び内容物その他調査報告書」）で、外食産 業の主な業態別に食材の使用量に占める生ご 
みの廃棄量を算出している。それによると、 例えばファミリーレストランAでは、生ごみ の発生量は、包装品を含んだ状態で60～ $70 \mathrm{~kg}$ /日で、調理くずと食べ残しの比率は $6 ： 4$ とのことである。同じく B では、生ごみは $17 \mathrm{~kg} /$ 日で、このうち調理くずが $12 \mathrm{~kg} 、$ 食べ 残しが $5 \mathrm{~kg}$ となっている。同じくCでは、生 ごみの発生量は 45〜 85kg /日で、このうち 調理くずが20～35kg、食べ残しが25～50kg となっている。他の業態としてファーストフ ードDでは、生ごみの発生量は 17 23kg / 日であるが、ほとんどが調理くずとなってい る。同じくEでは生ごみは $6 \sim 11 \mathrm{~kg} /$ 日で、 このうち調理くずが $2 \sim 3 \mathrm{~kg}$ 、食べ残しが 4 〜 $8 \mathrm{~kg}$ となっている。E社の食べ残しの主な ものは、チキンの骨である。同じくFでは、 平均 $16 \mathrm{~kg} /$ 日で、調理くずが約 $4 \mathrm{~kg}$ 、食べ 残しが約 $12 \mathrm{~kg}$ となっている。

このようにファーストフードでは、テイク アウト（持ち帰り）があることと、基本的に は加工度の高い食材を使用するため、生ごみ は比較的少ないという特徵がある。また同じ 業態であっても立地や営業時間、曜日、業 種、客数、使用食材 (例えば、カット野菜)、 店舗での加工度等の条件によって数值に相当 の開きが出る結果となっている。期限切れに よる食材・食品の廃棄量も正確には把握され ていない。このようなことから、外食産業の 業界団体である当協会では今年度、外食産業 における廃棄物の実態調査を実施し、基礎デ 一夕の充実を図る予定である。

しかしながら、一般的には調理くずの廃棄 量は企業努力でさらに抑制する方向にあり、 食品ロスを減少させるには食べ残しを防ぐこ とが必要である。その意味で、高齢化社会を 迎え外食産業では年齢層に沿った商品提供や 量を選択できるメニュー作り等が今後の課題 となっている。
食品ロスとフードシステムの取り組み

財日本容器包装リサイクル協会 池田 俊一

\section{1. ライフスタイルの変化}

昭和 30 年代半ば以降の高度経済成長期 に、生産と消費の構造が大きく変化し、また 女性の社会進出、核家族化が同時に進んだ。 二世帯、三世帯同居の減少は食文化の面で も、地域の特色を薄めて均一化が進んだ。物 質的豊かさを得たが、社会構造を見ると少子 化が進み高齢人口の構成割合が相対的に多く なっている。

2. 食生活のスタイルの変化

調理された料理を家族が時間差ありで喫食 する個食化が進み、好みに合わせて調理品も 異なる個食化が起こった。好きなものだけ食 ベることからくる食べ残しや廃棄の増加、少 量調理化で材料段階の無駄や廃棄を出すこと となり、半加工品や加工品を家庭食に取り込 むことが合理的と考えられるようになってき た。

\section{3. 社会システムの変化}

社会システムを見ても、大型物流センター や材料加工工場が造られ、技術的にも冷蔵・ 冷凍システムが完備し、家庭内にも大型の冷 凍・冷蔵庫が導入されコールドチェーンが供 給サイドから消費者の台所までつながった。 食品、食材のロスで見ると生産地や加工工場 でのロスが発生することとなった。

\section{4. 食品容器の変化}

プラスチックを中心とした比較的安いコス トでどんな形状の容器でも供給が可能となっ たことから、容量も大中小と簡単に制作で き、素材特性により組み合わせ複合化するこ とで中身の品質保持・保護が可能となった。 ただし、こらの容器の使用は廃棄物の処理 が従来の埋め立てや焼却処理では対応できが たくなった。

5. 容器包装リサイクル法の概要

容器包装リサイクル法は、ごみの量の増大 
と最終処分場のひっ迫等を背景として、消費 者には分別排出を、行政には分別収集に努 め、特定事業者は、指定法人に委託等で再商 品化の義務励行することを求めている。

6. 事業者の対応と社会的責任

今後事業者としては、容器包装廃棄物の発 生抑制や減量化に努める必要がある。また、 再生された製品の利用、利用されてできた製 品の利用についても積極的に進めることと し、リサイクルコストについては、価格転嫁 して広く国民が負担することとされている。 